\title{
Studies on Tissue Protease
}

\section{The in vivo Activation of Protease System and \\ Gluconeogenesis In Liver}

(Directed by Asst. Prof. M. Hayakawa)

By

\author{
Fumio Ito \\ (伊 藤 文雄)
}

\section{From Prof. Matunaga's Medical Clinic, Faculty of Medicine, Hirosaki University, Hirosaki}

(Received for publication, April 10, 1954)

In the preceding paper ${ }^{11}$ it was demonstrated that epinephrine produced remarkable augmentation of proteolytic enzyme system on liver, and it was suggested thereby that such phenomenon might relate to gluconeogenesis which should be carried into effect immediately after comsumption of glycogen deposit in liver. However, the relation to gluconeogenesis of adrenal cortex has been suggested by Long') and the protein catabolic effect of adrenal cortical substances is now rather common knowledge. On the other hand epinephrine is known as an effective activator for the pituitary-adrenal system. Regarding these matters further studies were made on in vivo activation of the liver protease system.

\section{EXPERIMENTAL}

The method was the same as the one employed in the preceding paper $^{21}$.

\section{Results}

Coinciding with preceding observations, epinephrine delivery through the systemic vein results in acceleration of heterolytic and autolytic proteolysis of liver and causes augmentation of tryptase as well as that of catheptic protease (Tables I, II \& III, Animal, No. 73). In this case the animal was killed four hours after epinephrine delivery, so its effect is shown to be able to continue at least four hours. Blood cell counts of the animal before and after the delivery are shown in Table IV. Eosinophil cell and lymphocyte counts fall apparently four hours after the delivery, i.e., response to the latter of its pituitary-adrenal system appears to be well preserved.

To determine whether or not epinephrine exerts its effect on liver protease system via such endocrine system, further experiments were carried 


\section{TABLE I}

Epinephrine Effect on Tryptic Proteolysis of Rabbit Liver at $\mathrm{pH} 7.8$

(Increases of acidity in $4 \mathrm{cc}$. digestion mixture (cc. of $0.1 \mathrm{~N} \mathrm{NaOH}$ ))

\begin{tabular}{|c|c|c|c|c|c|c|c|c|c|}
\hline \multirow{3}{*}{ Substrate* } & \multirow{3}{*}{$\begin{array}{l}\text { Time } \\
\text { in } \\
\text { hrs. }\end{array}$} & \multicolumn{8}{|c|}{ Animal (Source of enzyme solution) } \\
\hline & & \multirow{2}{*}{$\begin{array}{l}\text { No. } \\
73 \dagger\end{array}$} & \multicolumn{3}{|c|}{ adrenalectomized } & \multicolumn{3}{|c|}{ glucose administered } & \multirow{2}{*}{$\begin{array}{l}\text { Normal } \\
\text { control }\end{array}$} \\
\hline & & & No. 61 & No. 72 & No. 74 & No. 68 & No. 70 & No. 71 & \\
\hline $\begin{array}{l}\text { Casein } \\
\text { (a) }\end{array}$ & $\begin{array}{r}24 \\
72 \\
120\end{array}$ & $\begin{array}{l}0.25 \\
0.55 \\
0.75\end{array}$ & $\begin{array}{l}0.35 \\
0.6 \\
0.8\end{array}$ & $\begin{array}{l}0.35 \\
0.7 \\
0.85\end{array}$ & $\begin{array}{l}0.35 \\
0.7 \\
0.8\end{array}$ & $\begin{array}{l}0.15 \\
0.35 \\
0.35\end{array}$ & $\begin{array}{l}0.15 \\
0.35 \\
0.4\end{array}$ & $\begin{array}{l}0.15 \\
0.3 \\
-\end{array}$ & $\begin{array}{l}0.15 \\
0.25 \\
0.35\end{array}$ \\
\hline $\begin{array}{l}\text { Casein } \\
\text { (b) }\end{array}$ & $\begin{array}{r}24 \\
72 \\
120\end{array}$ & $\begin{array}{l}0.3 \\
1.2 \\
1.45\end{array}$ & $\begin{array}{l}0.35 \\
1.25 \\
1.55\end{array}$ & $\begin{array}{l}0.4 \\
1.2 \\
1.5\end{array}$ & $\begin{array}{l}0.4 \\
1.1 \\
1.5\end{array}$ & $\begin{array}{l}0.3 \\
0.6 \\
0.8\end{array}$ & $\begin{array}{l}0.3 \\
0.75 \\
0.8\end{array}$ & $\begin{array}{l}0.3 \\
0.65 \\
-\end{array}$ & $\begin{array}{l}0.3 \\
0.55 \\
0.7\end{array}$ \\
\hline $\begin{array}{l}\text { Casein } \\
\text { (c) }\end{array}$ & $\begin{array}{r}24 \\
72 \\
120\end{array}$ & $\begin{array}{l}0.45 \\
0.9 \\
1.2\end{array}$ & $\begin{array}{l}0.55 \\
0.95 \\
1.3\end{array}$ & $\begin{array}{l}0.5 \\
0.9 \\
1.35\end{array}$ & $\begin{array}{l}0.45 \\
0.8 \\
-\end{array}$ & $\begin{array}{l}0.4 \\
0.55 \\
0.75\end{array}$ & $\begin{array}{l}0.35 \\
0.65 \\
0.8\end{array}$ & $\begin{array}{l}0.3 \\
0.65 \\
-\end{array}$ & $\begin{array}{l}0.35 \\
0.5 \\
0.7\end{array}$ \\
\hline $\begin{array}{l}\text { Casein } \\
\text { (d) }\end{array}$ & $\begin{array}{r}24 \\
72 \\
120\end{array}$ & $\begin{array}{l}0.7 \\
1.4 \\
1.75\end{array}$ & $\begin{array}{l}0.75 \\
1.5 \\
1.85\end{array}$ & $\begin{array}{l}0.7 \\
1.55 \\
1.85\end{array}$ & $\begin{array}{l}0.1 \\
1.4 \\
\end{array}$ & $\begin{array}{l}0.55 \\
0.95 \\
1.05\end{array}$ & $\begin{array}{l}0.6 \\
0.95 \\
1.1\end{array}$ & $\begin{array}{l}0.6 \\
1.05 \\
-\end{array}$ & $\begin{array}{l}0.5 \\
0.9 \\
1.1\end{array}$ \\
\hline $\begin{array}{l}\text { Gelatin } \\
\text { (a) }\end{array}$ & $\begin{array}{r}24 \\
72 \\
120\end{array}$ & $\begin{array}{l}0.2 \\
0.25 \\
0.35\end{array}$ & $\begin{array}{l}0.2 \\
0.3 \\
0.35\end{array}$ & $\begin{array}{l}0.2 \\
0.25 \\
0.35\end{array}$ & $\begin{array}{l}0.3 \\
0.3 \\
0.35\end{array}$ & $\begin{array}{l}0.1 \\
0.2 \\
0.3\end{array}$ & $\begin{array}{l}0.1 \\
0.2 \\
0.25\end{array}$ & $\begin{array}{l}0.1 \\
0.15 \\
0.2\end{array}$ & $\begin{array}{l}0.1 \\
0.2 \\
0.3\end{array}$ \\
\hline $\begin{array}{l}\text { Gelatin } \\
\text { (b) }\end{array}$ & $\begin{array}{r}24 \\
72 \\
120\end{array}$ & $\begin{array}{l}0.3 \\
0.6 \\
0.75\end{array}$ & $\begin{array}{l}0.3 \\
0.65 \\
0.8\end{array}$ & $\begin{array}{l}0.35 \\
0.65 \\
0.85\end{array}$ & $\begin{array}{l}0.3 \\
0.65 \\
0.85\end{array}$ & $\begin{array}{l}0.3 \\
0.4 \\
0.5\end{array}$ & $\begin{array}{l}0.25 \\
0.4 \\
0.5\end{array}$ & $\begin{array}{l}0.15 \\
0.35 \\
0.55\end{array}$ & $\begin{array}{l}0.25 \\
0.4 \\
0.6\end{array}$ \\
\hline $\begin{array}{l}\text { Pepton } \\
\text { (a) }\end{array}$ & $\begin{array}{r}24 \\
72 \\
120\end{array}$ & $\begin{array}{l}0.7 \\
1.4 \\
1.5\end{array}$ & $\begin{array}{l}0.9 \\
1.6 \\
1.6\end{array}$ & $\begin{array}{l}0.9 \\
1.7 \\
1.7\end{array}$ & $\begin{array}{l}0.95 \\
1.7 \\
1.7\end{array}$ & $\begin{array}{l}0.75 \\
0.9 \\
0.95\end{array}$ & $\begin{array}{l}0.65 \\
0.8 \\
0.95\end{array}$ & $\begin{array}{l}0.6 \\
0.8 \\
0.95\end{array}$ & $\begin{array}{l}0.7 \\
1.0 \\
1.1\end{array}$ \\
\hline
\end{tabular}

Epinephrine doses : $2.0 \mathrm{mg}$. intravenously.

Animal: No. 73, 3.0 kg.; No. 61, $3.2 \mathrm{~kg}$; No. 72, $3.2 \mathrm{~kg}$.; No. 74, $3.4 \mathrm{~kg}$; No. $68,2.3 \mathrm{~kg}$; No. $70,3.0 \mathrm{~kg}$; No. $71,3.3 \mathrm{~kg}$.

* (a) without albumin or manganese activation ; (b) with dialyzed serum albumin solution; (c) with manganese activation (M/10- $\mathrm{MnSO}_{4}$ solution) ; (d) with combined activation with dialyzed serum albumin and manganese sulfate solutions.

+ Killed 4 hours after the epinephrine delivery.

$\ddagger$ Average of five animals (Nos. 35, 36, 45, 46 and 47).

out on animals adrenalectomized. On such animals, too, epinephrine casuses augmentation of liver protease system, and such effect is independent of pituitary-adrenal cortical system (Tables I, II \& III, Animals : Nos. $61,72 \& 74)$. Epinephrine itself exerts, however, no influence upon liver proteolysis in vitro when it is added directly with liver homogenates (Table V). Therefore its effect in vivo is indirect.

If such augmentation could be related directly to gluconeogenesis in 
TABLE II

Epinephrine Effect on Catheptic Proteolysis of Rabbit Liver at $\mathrm{pH} 4.5$

(Increases of acidity in 4 cc. digestion mixture; cc. of $0.1 \mathrm{~N} \mathrm{NaOH}$ )

\begin{tabular}{|c|c|c|c|c|c|c|c|c|c|}
\hline \multirow{3}{*}{ Substrate* } & \multirow{3}{*}{$\begin{array}{l}\text { Time } \\
\text { in } \\
\text { hrs. }\end{array}$} & \multicolumn{8}{|c|}{ Animal (Source of enzyme solution) } \\
\hline & & \multirow{2}{*}{$\begin{array}{l}\text { No. } \\
73 \dagger\end{array}$} & \multicolumn{3}{|c|}{ adrenalectomized } & \multicolumn{3}{|c|}{ administered glucose } & \multirow{2}{*}{$\begin{array}{l}\text { Normal } \\
\text { controlf }\end{array}$} \\
\hline & & & No. 61 & No. 72 & No. 74 & No. 68 & No. 70 & No. 71 & \\
\hline $\begin{array}{c}\text { Casein } \\
\text { (a) }\end{array}$ & $\begin{array}{r}24 \\
72 \\
120\end{array}$ & $\begin{array}{l}0.5 \\
1.05 \\
1.2\end{array}$ & $\begin{array}{l}0.6 \\
1.05 \\
1.2\end{array}$ & $\begin{array}{l}0.6 \\
1.05 \\
1.2\end{array}$ & $\begin{array}{l}0.65 \\
0.95 \\
1.25\end{array}$ & $\begin{array}{l}0.35 \\
0.4 \\
0.55\end{array}$ & $\begin{array}{l}0.3 \\
0.4 \\
0.5\end{array}$ & $\begin{array}{l}0.35 \\
0.45 \\
0.55\end{array}$ & $\begin{array}{l}0.25 \\
0.35 \\
0.45\end{array}$ \\
\hline $\begin{array}{l}\text { Casein } \\
\text { (b) }\end{array}$ & $\begin{array}{r}24 \\
72 \\
120\end{array}$ & $\begin{array}{l}0.9 \\
1.55 \\
1.8\end{array}$ & $\begin{array}{l}0.95 \\
1.3 \\
1.7\end{array}$ & $\begin{array}{l}0.9 \\
-\end{array}$ & - & $\begin{array}{l}0.55 \\
0.7 \\
0.8\end{array}$ & $\frac{0.5}{-}$ & - & $\begin{array}{l}0.45 \\
0.6 \\
0.75\end{array}$ \\
\hline $\begin{array}{l}\text { Gelatin } \\
\text { (a) }\end{array}$ & $\begin{array}{r}24 \\
72 \\
120\end{array}$ & $\begin{array}{l}0.65 \\
0.75 \\
0.9\end{array}$ & $\begin{array}{l}0.7 \\
0.8 \\
0.9\end{array}$ & $\begin{array}{l}0.75 \\
0.85 \\
0.9\end{array}$ & $\begin{array}{l}0.65 \\
0.8 \\
0.9\end{array}$ & $\begin{array}{l}0.35 \\
0.45 \\
0.6\end{array}$ & $\begin{array}{l}0.3 \\
0.35 \\
0.55\end{array}$ & $\begin{array}{l}0.25 \\
0.3 \\
0.6\end{array}$ & $\begin{array}{l}0.2 \\
0.35 \\
0.45\end{array}$ \\
\hline $\begin{array}{l}\text { Gelatin } \\
\text { (b) }\end{array}$ & $\begin{array}{r}24 \\
72 \\
120\end{array}$ & $\begin{array}{l}0.9 \\
1.2 \\
1.25\end{array}$ & $\begin{array}{l}0.9 \\
1.25 \\
1.25\end{array}$ & - & $\frac{-}{-}$ & $\begin{array}{l}0.55 \\
0.85 \\
0.85\end{array}$ & - & - & $\begin{array}{l}0.5 \\
0.7 \\
0.7\end{array}$ \\
\hline $\begin{array}{l}\text { Pepton } \\
\text { (a) }\end{array}$ & $\begin{array}{r}24 \\
72 \\
120\end{array}$ & $\begin{array}{l}0.55 \\
0.7 \\
0.9\end{array}$ & $\begin{array}{l}0.6 \\
0.7 \\
0.95\end{array}$ & $\begin{array}{l}0.5 \\
0.7 \\
0.9\end{array}$ & $\begin{array}{l}0.5 \\
0.7 \\
0.9\end{array}$ & $\begin{array}{l}0.4 \\
0.45 \\
0.55\end{array}$ & $\begin{array}{l}0.3 \\
0.4 \\
0.6\end{array}$ & $\begin{array}{l}0.35 \\
0.5 \\
0.6\end{array}$ & $\begin{array}{l}0.35 \\
0.55 \\
0.65\end{array}$ \\
\hline $\begin{array}{l}\text { Pepton } \\
\text { (b) }\end{array}$ & $\begin{array}{r}24 \\
72 \\
120\end{array}$ & $\begin{array}{l}0.75 \\
1.0 \\
1.1\end{array}$ & $\begin{array}{l}0.85 \\
1.2 \\
1.3\end{array}$ & - & - & $\begin{array}{l}0.55 \\
0.7 \\
0.8\end{array}$ & - & - & $\begin{array}{l}0.5 \\
0.75 \\
0.8\end{array}$ \\
\hline
\end{tabular}

Epinephrine dose: $2.0 \mathrm{mg}$. intravenously.

Animal, body weight $(\mathrm{kg}$.$) : No. 73,3.0$; No. $61,3.2$; No. $72,3.2$; No. $74,3.4$; No. 68 , 2.3 ; No. $70,3.0$; No. $71,3.3$.

* (a) without cystein, (b) with cystein activation.

$\dagger$ Killed 4 hours after the epinephrine delivery.

I Average of three animals (Nos. 45, 46 and 47).

liver it would be expected that the effect of epinephrine would be abolished under some conditions. Hyperglycemic state, for example, may account for such a condition, because there should be no need for gluconeogenesis and so none for protease augmentation. Therefore the effect of epinephrine was examined on three animals injected with $20 \mathrm{cc}$. of $10 \%$-glucose solution and kept beforehand in a hyperglycemic state (urine sugar). After epinephrine delivery blood sugar rose further of the three animals and fell in one animal (Table VI), and activity of liver protease system was, as was expected, by no means accelerated (Tables I, II \& III, Animals, Nos. $68,70 \& 71)$. Effect on liver protease system of epinephrine was thus abolished by prior administration of glucose solution. 


\section{TABLE III}

Epinephrine Effect on Catheptic Proteolysis of Rabbit Liver (Increases of acidity in cc. of $0.1 \mathrm{~N} \mathrm{NaOH}$ for $1 \mathrm{~g}$. liver.)

\begin{tabular}{|c|c|c|c|c|c|c|c|c|c|}
\hline \multirow{3}{*}{$\begin{array}{l}\mathrm{pH} \text { of } \\
\text { Autolysis }\end{array}$} & \multirow{3}{*}{$\begin{array}{l}\text { Time } \\
\text { in } \\
\text { hrs. }\end{array}$} & \multicolumn{8}{|c|}{ Autolytic proteolysis of the liver of animal } \\
\hline & & \multirow{2}{*}{$\begin{array}{l}\text { No. } \\
73^{*}\end{array}$} & \multicolumn{3}{|c|}{ adrenalectomized } & \multicolumn{3}{|c|}{ administered with glucose } & \multirow{2}{*}{$\begin{array}{l}\text { Normal } \\
\text { control } \dagger\end{array}$} \\
\hline & & & No. 61 & No. 72 & No. 74 & No. 68 & No. 70 & No. 71 & \\
\hline \multirow{3}{*}{4.5} & 24 & 1.9 & 2.2 & 2.2 & 2.15 & 1.5 & 1.4 & 1.55 & 1.5 \\
\hline & 72 & 2.7 & 2.8 & 2.85 & 2.95 & 2.15 & 2.1 & 2.1 & 2.1 \\
\hline & 120 & 3.0 & 3.25 & 3.3 & 3.45 & 2.45 & 2.4 & 2.5 & 2.5 \\
\hline \multirow{3}{*}{7.8} & 24 & 0.9 & 1.05 & 0.95 & 0.95 & 0.4 & 0.45 & 0.4 & 0.4 \\
\hline & 72 & 1.1 & 1.25 & 1.25 & 1.25 & 0.7 & 0.6 & 0.6 & 0.55 \\
\hline & 120 & 1.35 & 1.5 & 1.45 & 1.65 & 0.9 & 0.9 & 0.85 & 0.85 \\
\hline
\end{tabular}

Epinephrine dose: $2.0 \mathrm{mg}$. intravenously.

* Killed 4 hours after the epinephrine delivery.

$\dagger$ Average of three animals (Nos. 45, 46 and 47).

TAB LE IV

Blood Picture of Animal No. 73 before and after the Epinephrine Delivery*

\begin{tabular}{l|c|c}
\hline & Before & After \\
\hline Eosinophil† cell count & 250 & 75 \\
Leucocyte count & 15,000 & 22,000 \\
Lymphocyte & 5,150 & 3,630 \\
count & $(52)$ & $(17.5)$ \\
(\%) & $\%$ & $\%$ \\
Neutrophil & 4,050 & 17,380 \\
cell count & $(40.5)$ & $(79.0)$ \\
$(\%)$ & $\%$ & $\%$
\end{tabular}

* Animal No. 73, $3.0 \mathrm{~kg}$. delivered with $2.0 \mathrm{mg}$. epinephrine through the system vein and killed four hours after the delivery.

$\dagger$ According to Dunger's method.

Prior administration of $10 \mathrm{cc}$. of $10 \%$-alanin solution which was thought to be a effective precursor of glucose was also shown to prevent similarly augmentation of tryptase or retard that of catheptase, and epinephrine exerts no remarkable effect on tryptic proteolysis of the liver of animal treated with it a short time after a meal (Table VII).

Therefore, the above assumption that enzyme augmentation may relate to gluconcogenesis appears to be founded in these facts observed.

Epinephrine is, on the other hand, known also to accelerate glycogenolysis of muscle, therefore, its effect on muscle proteolysis was examined. 


\section{TABLE V}

Influence of Epinephrine upon Liver Proteolysis* in vitro

(Increases of Acidity in 4 cc. digestion mixture; cc. of $0.1 \mathrm{~N} \mathrm{NaOH}$ )

\begin{tabular}{c|c|c|c|c|c}
\hline \multirow{2}{*}{ Substrate } & \multirow{2}{*}{$\begin{array}{c}\text { Time } \\
\text { in } \\
\end{array}$} & \multicolumn{5}{|c}{$0.1 \%$-epinephrine, cc. } \\
\cline { 3 - 6 } & hrs. & 0 & 0.5 & 1.0 & 2.0 \\
\hline & 24 & 0.15 & 0.15 & 0.15 & 0.15 \\
$2 \%$ & 72 & 0.25 & 0.3 & 0.25 & 0.25 \\
Casein & 120 & 0.35 & 0.35 & 0.3 & 0.35 \\
& 24 & 0.6 & 0.6 & 0.65 & 0.6 \\
& 72 & 0.75 & 0.7 & 0.75 & 0.7 \\
$2 \%$ & 120 & 0.9 & 0.95 & 0.85 & 0.9
\end{tabular}

* Normal liver (animal No. 63, $3.2 \mathrm{~kg}$.).

$20 \mathrm{cc}$. substrate-buffer ( $\mathrm{pH} 7.8$ ) solution $+2 \mathrm{cc}$. enzyme solution (liver homogenate

1: glycerin water 3$)+0-2.0 \mathrm{cc}$. epinephrine solution $+2.0-0 \mathrm{cc}$. buffer solution

Epinephrine treatment for enzyme solution :

$2 \mathrm{cc}$. original enzyme solution was added with $0-2.0 \mathrm{cc}$. $0.1 \%$-epinephrine solution and $2.0-0 \mathrm{cc}$. buffer solution and incubated at $37^{\circ} \mathrm{C}$ for forty minutes (final volume being made $4 \mathrm{cc}$. respectively).

\section{TABLE VI}

Change of Blood Sugar $(\mathrm{mg} / \mathrm{dl})$ after Glucose Administration and Epinephrine Delivery

\begin{tabular}{c|c|c|c}
\hline Animal No. & Before & After glucose & After epinephrine \\
\hline 68 & 114 & 460 & 480 \\
70 & 121 & 509 & 380 \\
71 & 129 & 509 & 543
\end{tabular}

Muscle tryptase is, in native state, low in activity as was so when previously observed $^{3)}$. In the case of epinephrine or insulin delivery no change in tryptase or ereptase activity was observed (Table VIII).

\section{Discussion}

Although catabolic effect of adrenal cortical substance is well established, relationship between this and gluconeogenesis or details of biological mechanism of the latter has not yet been elucidated.

From the results presented above epinephrine is evidenced to cause, independent of the adrenal cortex, augmentation of the liver protease system and this should be interpreted as indicating increase in the rate of protein metabolism which should directly relate to gluconeogenesis ad- 


\section{TABLE VII}

Influence of Prior Administration of Alanin etc. upon

Epinephrine Effect on Rabbit Liver Proteolysis

(Increases of acidity in $4 \mathrm{cc}$. digestion mixture (cc. of $0.1 \mathrm{~N} \mathrm{NaOH}$ )).

\begin{tabular}{|c|c|c|c|c|c|c|c|c|}
\hline \multirow{2}{*}{$\begin{array}{c}\text { Animal } \\
\text { No. }\end{array}$} & \multirow{2}{*}{$\begin{array}{c}\text { Time } \\
\text { in } \\
\text { hrs. }\end{array}$} & \multicolumn{4}{|c|}{ pH 7.8} & \multicolumn{3}{|c|}{$\mathrm{pH} 4.5$} \\
\hline & & $\begin{array}{c}\text { Casein } \\
(\mathbf{a})^{*}\end{array}$ & $\begin{array}{c}\text { Casein } \\
\text { (b) } \dagger\end{array}$ & Gelatin & Pepton & Casein & Gelatin & Pepton \\
\hline $86 \ddagger$ & $\begin{array}{r}24 \\
72 \\
120\end{array}$ & $\begin{array}{l}0.15 \\
0.2 \\
0.3\end{array}$ & - & $\begin{array}{l}0.1 \\
0.15 \\
0.15\end{array}$ & $\begin{array}{l}0.45 \\
0.95 \\
1.0\end{array}$ & - & - & - \\
\hline $106 \S$ & $\begin{array}{r}24 \\
72 \\
120\end{array}$ & $\begin{array}{l}0.1 \\
0.2 \\
0.2\end{array}$ & $\begin{array}{l}0.2 \\
0.3 \\
0.5\end{array}$ & $\begin{array}{l}0.1 \\
0.15 \\
0.15\end{array}$ & $\begin{array}{l}0.45 \\
0.75 \\
0.75\end{array}$ & $\begin{array}{l}0.3 \\
0.45 \\
0.65\end{array}$ & $\begin{array}{l}0.35 \\
0.6 \\
0.7\end{array}$ & $\begin{array}{l}0.25 \\
0.5 \\
0.55\end{array}$ \\
\hline Normal// & $\begin{array}{r}24 \\
72 \\
120\end{array}$ & $\begin{array}{l}0.15 \\
0.25 \\
0.35\end{array}$ & $\begin{array}{l}0.3 \\
0.55 \\
0.7\end{array}$ & $\begin{array}{l}0.1 \\
0.2 \\
0.3\end{array}$ & $\begin{array}{l}0.7 \\
1.0 \\
1.1\end{array}$ & $\begin{array}{l}0.25 \\
0.35 \\
0.45\end{array}$ & $\begin{array}{l}0.2 \\
0.35 \\
0.45\end{array}$ & $\begin{array}{l}0.35 \\
0.55 \\
0.65\end{array}$ \\
\hline
\end{tabular}

* Without albumin.

$\dagger$ With dialyzed serum albumin solution.

$\ddagger$ Epinephrine delivery short time after meal.

$\S$ Prior administration of $1 \mathrm{~g}$. alanin.

// Cf. Tables I and II.

TABLE VIII

Influence of Epinephrine upon Tryptic Proteolysis of

Striped Muscle of Rabbit

(Increases of acidity in $4 \mathrm{cc}$. digestion mixture (cc. of $0.1 \mathrm{~N} \mathrm{NaOH}$ )).

\begin{tabular}{|c|c|c|c|c|c|}
\hline \multirow{2}{*}{$\begin{array}{l}\text { Animal No. } \\
\text { (body } \\
\text { weight, kg.) }\end{array}$} & \multirow{2}{*}{$\begin{array}{l}\text { Time } \\
\text { in } \\
\text { hrs. }\end{array}$} & \multicolumn{3}{|c|}{ Hydrolysis at $\mathrm{pH} 7.8$ of } & \multirow{2}{*}{ Remarks } \\
\hline & & Casein & Gelatin & Pepton & \\
\hline $\begin{array}{l}64 \\
(3.2)\end{array}$ & $\begin{array}{r}24 \\
72 \\
120\end{array}$ & $\begin{array}{l}0.2 \\
0.3 \\
0.35\end{array}$ & $\begin{array}{l}0.05 \\
0.1 \\
0.25\end{array}$ & $\begin{array}{l}0.25 \\
0.45 \\
0.6\end{array}$ & normal control \\
\hline $\begin{array}{l}67 \\
(3.0)\end{array}$ & $\begin{array}{r}24 \\
72 \\
120\end{array}$ & $\begin{array}{l}0.1 \\
0.25 \\
0.4\end{array}$ & $\begin{array}{l}0.05 \\
0.1 \\
0.2\end{array}$ & $\begin{array}{l}0.2 \\
0.45 \\
0.6\end{array}$ & $0.5 \mathrm{mg}$. epinephrine intravenously \\
\hline $\begin{array}{l}68 \\
(2.3)\end{array}$ & $\begin{array}{r}24 \\
72 \\
120\end{array}$ & $\begin{array}{l}0.1 \\
0.25 \\
0.35\end{array}$ & $\begin{array}{l}0.05 \\
0.15 \\
0.2\end{array}$ & $\begin{array}{l}0.3 \\
0.45 \\
0.55\end{array}$ & $\begin{array}{l}\text { glucose }(10 \mathrm{~g} .) \text { administration prior } \\
\text { to epinephrin delivery }(2 \mathrm{mg} .)\end{array}$ \\
\hline $\begin{array}{l}69 \\
(3.3)\end{array}$ & $\begin{array}{r}24 \\
72 \\
120\end{array}$ & $\begin{array}{l}0.15 \\
0.2 \\
0.3\end{array}$ & $\begin{array}{l}0.05 \\
0.15 \\
0.15\end{array}$ & $\begin{array}{l}0.3 \\
0.55 \\
0.6\end{array}$ & Insulin delivery (200 units) \\
\hline
\end{tabular}

vancing therein. From such point of view it is concluded that gluconeogenesis in the liver does not require the presence of adrenal cortex. Selye ${ }^{4}$ 
is of the opinion that the corteicoid aids rather the utilization of protein catablites for gluconeogenesis or protein re-synthesis. And it was concluded by Ingle $^{5}$ that the negative nitrogen balance after traumatic injury is not caused specially by the increase in secretion of the cortical hormones.

Referring to catabolic effect of adrenal cortex, Bondy ${ }^{6)}$ showed that it did not require the presence of the liver. That epinephrine causes augmentation of the liver protease system independent of adrenal cortex is, therefore, compatible with Bondy's results. According to Selye ${ }^{4)}$ the breakdown of body protein, except those of lymphocytes, takes place independent of the adrenal cortex. White and Doughtery' showed on fasting mice that a decrease in nitrogen content was seen in livers of adrenalectomized animals as well as in those not operated on. These observations show the possibility that protein metabolism of the liver can progress regardless of adrenal cortex and that it is controlled by a mechanism other than that of metabolism of the other body protein. From the results obtained, epinephrine, namely adrenal medulla or sympathic nerve, is concluded to be a factor which controls the metabolism of liver protein.

But it is very interesting that glucose or alanin is antagonistic to the effect of epinephrine, as was so in the experiments conducted by Engel ${ }^{8 \text { ) }}$ on the effect of adrenal cortical extract. Bondy ${ }^{6}$ ) showed such effect of glucose to be carried out in the periphery to the liver, but detail of mechanism of antagonistic effect against epinephrine of glucose or alanin is open to question. These substances are, at least, said to spare the liver protein in occasion of "emergency reaction".

Engle $^{8)}$ considered the effect of adrenal cortex on protein metabolism was secondary to the changes in the carbohydrate/fat metabolism. From the above the effect of epinephrine should be indirect upon the protease system itself, and the augmentation of liver protease system, namely, the increase in the rate of protein metabolism, should also be considered to be brought into effect secondary to glycogenolysis and corresponding with gluconeogenesis directly. It is suggested that gluconeogenesis occurs first with consumption with liver protein. The protein catabolites which could come from other tissue proteins under adrenal cortical influence may serve for the re-synthesis of liver protein or directly for gluconeogenesis. The role of adrenal cortex for gluconeogenesis may be explained as supplying amino acid to the liver and or sparing liver protein.

\section{Summary}

1. Epinephrine delivery in vivo causes augementation of the liver protease system on animals fasted for twenty four hours. But no change in protease activities is seen in vitro when epinephrine is directly added to 
liver homogenates.

2. Such phenomenon is observed in the absence of adrenal cortex but not observable on animals treated with epinephrine a short time after a meal.

3. Prior administration of glucose or alanin prevents epinephrine effect, i.e., no augmentation of protease system is seen.

4. Tryptic muscle proteolysis remains unaffected after epinephrine treatment.

5. The biological mechanism of gluconeogenesis is briefly discussed with enzyme augmentation phenomenon.

This work was carried out by a grant for development of scientific researches, given from the Ministry of Education. M. Hayakawa

\section{References}

1) Ito, Tohoku J. Exp. Med., 1955, 61, 389.

2) Long, Katzin \& Fry, Endocrinology, 1940, 26, 309.

3) Hayakawa \& Ito, Tohoku J. Exp. Med., 1954, 60, 353, 361.

4) Selye, Textbook of Endocrinology. 2nd Ed., Montreal, 1949, 843.

5) Ingle et al., Amer. J. Physiol,, 1947, 149, 510.

6) Bondy, Endocrinology, 1949, 45, 605.

7) White \& Doughtery, ibid., 1947, 41, 230.

8) Engel, Schiller \& Pentz, ibid,, 1949, 44, 458. 